\title{
SETTING THE GROUND FOR GLOBAL CITY FORMATION: NEOLIBERALISATION AND LOCAL ELITES IN FRANKFURT ON THE MAIN
}

\author{
SAMUel Mössner, Tim Freytag \\ Institute of Environmental Social Sciences and Geography, University of Freiburg, Germany
}

Manuscript received: February 3, 2014

Revised version: March 5, 2014

\begin{abstract}
Mössner S., FreYtAG T., 2014. Setting the ground for global city formation: Neoliberalisation and local elites in Frankfurt on the Main. Quaestiones Geographicae 33(4), Bogucki Wydawnictwo Naukowe, Poznań, pp. 81-88, 1 fig. DOI 10.2478/ quageo-2014-0051, ISSN 0137-477X.

ABSTRACT: This paper approaches the global city concept from a local perspective taking into account the political action of local elites in times of urban neoliberalisation. Drawing on the empirical research carried out in Frankfurt (Main), we argue that the very beginnings of the global city formation were less a result of global processes superseding local ones, as is often argued, but rather emerged out of local political action contested by local protests. In the first part, we will revisit the global city concept and contrast it against a critique of urban neoliberalisation. The second focuses on reviewing the history of urban restructuring in the Frankfurt Westend during the 1960s and 1970s. We suggest that the transformation of the Westend into a "strategic site of global control" (Sassen 2011) has been constructed as a narrative in order to legitimise local forms of real estate speculation, marketisation of commodification. Our paper tries to unfold the logics and strategies of such neoliberal urbanisation by critically reflecting upon historical events since the 1960s.
\end{abstract}

KEY WORDS: global city, Frankfurt (Main), urban neoliberalisation, protest movements

Samuel Mössner, Institute of Environmental Social Sciences and Geography, University of Freiburg, Werthmannstr. 4, 79085 Freiburg, Germany; e-mail: samuel.moessner@geographie.uni-freiburg.de

\section{Introduction}

The emergence of global cities has been among the most prominent urban phenomena of the past decades in urban geography. New forms of "hypermobilisation, global communications and the neutralisation of place and distance" (Sassen 2011: 55) have heralded a new geography of economic globalisation. Practitioners, policy-makers as well as researchers from the various fields of urban studies have extensively studied, documented and written about the rise of global cities and their regions as a specific form of re-localisation within a system of global capitalist urbanisation. A simple Google-search of the term 'global city' on the Internet results in an impressive number of more than 10 million hits, and the Google-scholar lists roughly 35,000 academic entries (google.de and google-scholar.de in April 2013).

Since the term 'global city' first emerged in the academic literature, it has become popular in reconsidering the importance of specific localities within an economic system of globalised information and monetary flows. Thereby, the global city has been both a term for describing a new form of global urbanisation as well as a conceptual approach that describes and explains global capitalist development. When economic restructuring impeached traditional concepts of the ur- 
ban in the Western hemisphere due to worldwide de- and new industrialisations, the global city occurred as a promising conceptual container for grasping these new processes within the corset of traditional urban theory.

The global city concept starts with the premise that all urbanisation is a result of global economic activities that determine local forms, functions, people and imaginations. It is based on the belief that the economic structure creates spatial disparities and social inequalities by a differentiated accumulation of economic power and control. Consequently, some cities are more deeply embedded in global flows of information, money, etc. than others. The emergence of new centralities influences the global system of urbanisation. Global cities have been conceptualised as a "transnational system of spatially concentrated human settlements" (Friedmann in Brenner, Keil 2006: 4) or as "strategic sites where global processes materialise" (Sassen 2011: 56). While some researchers analyse the relationship between the global that supersedes the local, others highlight the temporality of global and local processes (Swyngedouw 1997).

The strength of the global city concept lies in its ability to combine, reconcile and connect different traditions of thinking about the urban. For a long time, the global city has been discussed as a capitalist concept that describes the urban as a specific form of socio-spatial order (Sassen 2011: 59). Focusing on order, however, political action is neglected as a determining factor. Following the French philosopher Alain Touraine (2001), this article seeks to understand the formation of the global city as a specific form of (local) political action that emerges in the fold of a specific political-economic tradition.

By doing so, the article approaches the global city concept from a local perspective taking into account the political action of local elites in Frankfurt on the Main, Germany. Drawing on the example of Frankfurt, we argue that the very beginnings of its global city formation were less a result of global processes superseding the local ones, but rather emerged out of local political action contested by local forms of urban protest. In the first part of this paper, we will revisit the global city concept. The second part tells the story of urban restructuring in the Frankfurt West- end during the 1960s and 1970s. Our paper tries to unfold the logics and strategies of neoliberal urbanisation and global city formation by critically reflecting upon historical events since the 1960s. Moreover, we want to stimulate the ongoing debate on the major driving forces of recent developments in urban internationalisation and globalisation.

\section{The global city concept revisited}

Over more than 50 years a large body of literature has accumulated that describes globalisation as a transformation in terms of economic activities. However, the ascendance of information technologies and the increasing mobility of goods and commodities, individuals as well as capital have dramatically challenged our fundamental understanding of territorialisation (Sassen 2005). Besides its economic implications, globalisation has profoundly changed the socio-spatial arrangement of our daily-life activities. In 1996, Manuel Castells proposed a new analytical perspective on spatial reconfigurations that takes into account global dynamics by distinguishing between a 'space of flows' and a 'space of places'. The space of flows is constituted by transnational capital accumulations built around borderless information flows and weak-tie social networks (Castells 1996, new edition 2000). Even though this includes a territorial dimension that connects functions and people located in specific places (Castells 2000: 14), social relations tend to be de-territorialised in terms of weak territorial identities (Mitchell 2000). The space of flows contrasts with the space of places in which meaning, function, and locality are closely interrelated (Castells 2000: 14). Castells argues that the space of places has been superseded by the space of flows that has become the predominant spatial scale in our globalised world. As a result, today's social relations are increasingly dis-embedded from their local-territorial preconditions. Castells' work has inspired many researchers to focus on the "accelerated circulation of people, commodities, capital, money, identities and images through global space" (Brenner 1999: 431) linking economic aspects of globalisation to cultural transformations. Much of the work has fo- 
cused on the process of de-territorialisation that dis-embeds place-based identities out of their local context, making it difficult to maintain a stable sense of local identity in day-to-day life. This perspective of de-territorialisation was complemented by Neil Brenner's approach of territorial re-scaling $(1999,2004)$. Drawing on David Harvey and Henri Lefebvre, Brenner argues that globalisation must not be viewed as a form of de-territorialisation, but as a spatial "reconfiguration and re-scaling of forms of territorial organisation such as cities and states" (Brenner 1999: 432). Even though the national scale has lost part of its predominance, global flows of capital, information and image production re-territorialise at the level of cities and city-regions. The concept of 'glocalisation' is an attempt to consider both, the global trends that constantly act as structural forces upon cities and places, and the role of local resources and specificities that may add to this transformation process in the sense of an ongoing amalgamation of the global and the local (Swyngedouw 1997).

Global cities have emerged as central places of power and cooperation within an increasingly globalised world economy in the last decades. Drawing on Castells' reading of globalisation, the phenomenon of spatial concentration within global cities and the new hierarchy of a world economy were explored by Peter Hall (1966), John Friedmann (1986), Saskia Sassen (1994, 2001) and other leading international scholars. By now, there is a huge body of literature that helps understand the process of global city formation and its economic, social and territorial implications, including the formation of a new global network (Harrison, Growe 2012) as well as a progressive socio-economic polarisation and internal fragmentation (Brenner, Keil 2006). A key concern of Peter Taylor was to understand global cities as part of a space of flows (Castells 1996). In doing so, Taylor (2004) conceptualised the 'world city network' consisting of headquarters and offices of financial institutions and other important actors in the knowledge-based service economy, such as law and accountancy firms, insurance companies, transport logistic providers, etc. According to the hierarchy elaborated by Loughborough University's Globalisation and World City research group (GaWC), Frankfurt is considered a leading European global city. Within this strand of literature, however, the economy still remains the dominant factor of constructing transnational communities across very few cities. Luke claims that instead of "focusing on that handful of Global Cities which serve as the nodes in network for global capitalism, we need to ask instead about the collective impact of all 'global cities'" (Luke 2006: 277). He criticises the predominant perspective on global cities that presents them "typically in a fairly conventional manner" as "limited in numbers, tightly interconnected in function, located in the centre or semi-periphery of the world economy" (ibid.) and - most importantly - driven by abstract forces. However, when discussing the forces that drive global urbanisation it often appears that the local is considered as normatively positive and as being a victim of the oppressing forces of globalisation. Globalisation, in turn, occurs as the unalterable future, the inescapable constraints that have to be accepted as new natural laws of urban development.

When critically approaching the driving forces and actors that build the global cities, it seems to be promising to draw on a strand of urban theory that critically approaches the politics of place. Although largely discussed (Jonas, Wilson 1996), the concept of urban growth machines seems to be particularly suitable for interpreting the constellation of urban political actors. The urban growth machine approach focuses on individual action and interrelationships of human agents within the context of urban change and urban development (Harding 1995). It draws upon the work of Logan and Molotch from the mid-1980s, who outlined in their book (Logan, Molotch 1987) "the most systematic recent attempt to develop a political economy of "place'"' (Harding 1995). In the very centre of their approach stands a set of allies favouring a transformation of the urban structure aimed at an increase in the exchange-value of private property in order to create economic growth improving the wealth and prosperity of all citizens. Urban growth machines are not limited to economic upgrading of assets, but are usually concerned with a profound change of a whole urban structure.

In the very centre of urban growth machines are political representatives (not necessarily, but at least in the German context this is very common) along with private investors and entrepre- 
neurs shaping the urban system. Within an urban growth machine, there are both local and non-local actors who benefit directly or indirectly from changing urban environments. The importance of the growth machine approach lies in its central aspect: that urban change and transformation are not necessarily and exclusively an output of political decisions, but emerge due to a close interrelationship of public and private actors following mainly economic objectives and leading to a social transformation. Today, such actor-constellations are often discussed in terms of urban governance (Mössner 2010). Urban growth machines usually have very clear and rationally outlined objectives; urban transformation is limited to certain neighbourhoods and aimed at fostering economic growth by transforming the built environment. Therefore, the objectives of growth machine's rentiers can be distinguished from that of civil society: interests of rentiers and interests of neighbourhood inhabitants are considered to be usually opposed to each other. This was also the case when Frankfurt started to become a global city.

The global city concept appeared at the same time when leading scholars started to formulate a critique of economic urban neoliberalisation that started as a "utopian intellectual movement" (Peck, Tickell 2002: 380). Neoliberalism has its roots in the Freiburg School of ordo-liberalism (Hannah 2012) that advocated individual freedom "against the power of the state and of private agents" (Kerber, Hartig 1999: 342). Demanding a free market economy, Freiburg's ordo-liberalists developed an institutional framework of rules that guarantees a competitive order within which the market operates with minimalist public regulations. The Freiburg School of post-war German economists has influenced Friedrich August von Hayek, who - together with Milton Friedman - is considered one of the intellectual co-founder of neoliberalism (Brenner, Theodore 2002: 2). While there are many different streams and variants of liberalism, most of them underline the importance and centrality of individual will and freedom. Today, neoliberalism has become worldwide "common sense" (Peck, Tickell 2002: 381) in urban politics and is considered "the most recent articulation of the capitalist mode of production" (Walks 2009: 346). In the last decade an exten- sive literature has emerged dealing with urban neoliberalism (Eijk 2010; Mayer 2007; Mattissek 2008; Michel 2010; Swyngedouw et al. 2002; Theodore, Peck 2011). These authors have critically approached neoliberalism by stretching out its destructive forces and contradictory dependency on public regulations. They have shown that neoliberalism has been accepted by global elites as a project that equates unregulated markets with individual freedom.

\section{Global city formation in Frankfurt}

After World War II Frankfurt effectively reconnected to its traditions as an important location for international banking and monetary institutions, and quickly reassumed its position as a financial city in Germany's heterogeneous urban system (Noller, Ronneberger 1995). This process of redeveloping and even strengthening the dominant position within the global financial business market started only a short time after 1945, when Frankfurt citizens had accomplished the difficult task of reconstructing the tremendous damages of large parts of the city caused by the war. Today, according to the Frankfurt Chamber of Commerce and Industry (IHK), the city is ranked fourth among the global leading financial capitals, only beaten by New York City, London and Tokyo. Freytag et al. (2006) confirm that Frankfurt plays a leading role in the financial and transport sectors. In particular, its European-wide leading economic position arises among others from the presence of the Frankfurt Stock Exchange (Deutsche Börse AG), the Federal Bank of Germany (Deutsche Bundesbank) and, since the 1990s, the European Central Bank. Furthermore, Frankfurt offers a place to global players in the service sector, such as the Messe Frankfurt Group, which, according to their own statement, is the world's largest trade-fair organiser. It is this post-Fordist urban economy - including financial and service sectors - that constitutes the foundations of a global city (Brenner, Keil 2006) and the presence of these economic business branches are often, but not exclusively, addressed to identify a city's global position (Latham et al. 2009).

The global city transformation of Frankfurt started already in the 1960s (Keil, Ronneberger 
2000) when it positioned itself as a growing regional hub - first for the German national economy, and later within global financial flows. In 1965, the local government that consisted of a social democratic and conservative coalition launched a new inner-city urban development plan (City-Erweiterungsplan) in order to deal with the new economic internationalisation. This plan was aimed at extending the inner city into the Westend, a residential upper-class neighbourhood built in the middle of the $19^{\text {th }}$ century, where also migrants and students rented apartments. This development plan promised a large-scale restructuring of the Westend, transforming the residential neighbourhood into an urban area dominated by the service sector and financial institutions. The city administration aimed at implementing the development plan with the help of private capital and encouraged investors to buy adjacent properties that would allow a realignment of allotments and therefore facilitate the construction of high-rise buildings and skyscrapers. In the city development plan, the 'roof gable index' (in German 'Dachgiebelindex', a traditional measure limiting the height of buildings), was suspended for larger areas of more than one building lot. Furthermore, apartments were no longer limited to residential use, but could be used for other functions as well. Consequently, from the mid-1960s onwards, private investors started intensive real-estate speculations by either buying residential buildings for converting them into offices or demolishing entire lots to facilitate the construction of high-

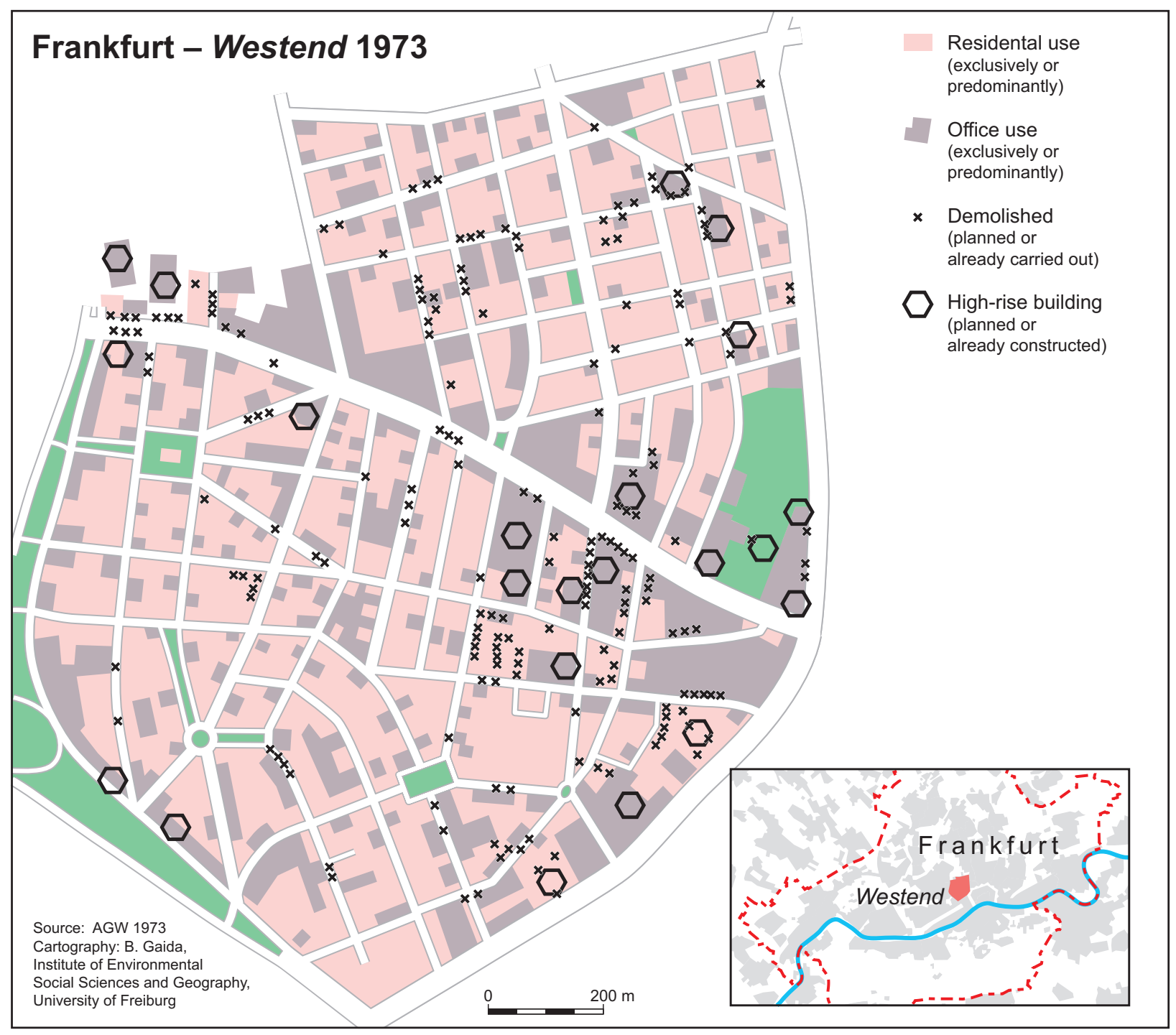


rise buildings that today dominate the Frankfurt skyline.

Between 1962 and 1972 the number of residents in the Westend diminished by $22 \%$, from 38,979 to 30,570 (Statistisches Wahlamt der Stadt Frankfurt, January 1974). According to contemporary witnesses, property prices increased at the same time from around $500 \mathrm{DM}$ (approximately 250 EUR) to 3,000 DM (1,500 EUR) per square metre. Reportedly, some grounds reached prices of 5,000 to 8,000 DM (2,500 to 4,000 EUR). Figure 1 illustrates the dynamics of this transformation process.

A first resistance against the city development plan emerged on October $10^{\text {th }} 1965$, when 7,500 signatures were collected against the development of a park area in the Westend. On April 14 ${ }^{\text {th }}$ 1969, forty persons founded the Aktionsgemeinschaft Westend action group, Germany's first citizens' initiative that addressed the negative outputs of speculation and the redevelopment plan, and started to organise the protest against further demolition of the Westend. In the same year, the local churches expressed their support for the Aktionsgemeinschaft and at the end of the year a pamphlet was published entitled 'The End of the Westend' (Das Ende des Westends). Surprised by the strong protests of the civil society, the city government declared that the development plan would be suspended on January $1^{\text {st }} 1970$. As private speculation continued, the Aktionsgemeinschaft wrote an open letter to the investors explaining the dramatic consequences of the investment activities and trying to convince the investors to stop this kind of real-estate speculation. On August $8^{\text {th }} 1970$ the first mass demonstration in the Westend occurred and in the night from August $18^{\text {th }}$ and $19^{\text {th }}$ the first building was squatted in Eppsteiner Straße 47. By 1972 more than 30 buildings had been squatted, which marked the beginning of the Frankfurt House-by-House Struggle (Frankfurter Häuserkampf) that can be regarded as a second phase of resistance.

Most of the approximately 50 investors involved in real-estate speculation in the Westend were Frankfurt-based local financiers that had been active in the city's real-estate sector for a long time. Among the most prominent investment companies were those of Ali Selmi, and of Ignatz and Ida Bubis (that allegedly - according to a hand-written list dated back to March $17^{\text {th }}$ 1979 - owned alone more than 511,178 square metres of residential space to be converted into office space). Both Selmi and the Bubis were also deeply involved in local politics. When the regional government enacted a law against the conversion of residential apartments into office use, these prominent investors circumvented legal limitations with the help of the local administration. The protest of the 1970s could not prevent the growth machine from transforming the neighbourhood (Noller, Ronneberger 1995).

\section{The global city as local neoliberal growth strategy}

As most old industrial cities, Frankfurt has been shaped by the abandonment of the Keynesian welfare-state regime in the 1960s as a result of economic restructuring. Even though the processes of de-industrialisation have been less profound for urban society compared with other European industrialised areas, since the 1960s a neoliberal strategy emerged aimed at deregulating housing markets arguing with the constraints of a new global competition that the city is part of. On the very basis of neoliberal political strategies stands the idea of "open, competitive, and unregulated markets, liberated from all forms of state interference" (Brenner, Theodore 2002: 2) that has been broadly criticised for its perception of market rules as a "state of nature" (Peck, Tickell 2002: 382).

Drawing on the different phases of urban neoliberalisation, the transformation of the Westend can be analysed as a result of commodification of the marketisation of the neighbourhood. Since neoliberalism is understood "as a process, not an end-state" (Peck, Tickell 2002: 383) - thus preferring the term neoliberalisation instead of neoliberalism - Peck and Tickell (2002) identified two phases of what they call "roll-back" and "rollout" neoliberalism. The roll-back phase started when the philosophical idea of "proto-neoliberalism" turned into political praxis. There were profound cuts in welfare and public funding, and most social benefits, introduced to facilitate the exploitation of human labour during indus- 
trialisation, became privatised and de-regulated, dismantling the Keynesian welfare state. When cut-backs of public funding resulted in a more and more difficult situation encountering "institutional and political limits" (Peck, Tickell 2002: 388) that individualism and market centrism have created, the state introduced flanking mechanisms in order to stabilise the contradictions created by the economic system as "modes of crisis displacement" (Mayer 2007: 91). These mechanisms include, inter alia, new forms of coordination and governance (Mayer 2007), financial regulations at the global scale (Aguirre et al. 2006), and welfare-to-work approaches (Mayer 2003), which pay tribute to individualism by introducing case-management to welfare provision. This happened in the 1980s, a decade after the protest movements and the squatting of the Eppsteiner Straße 43, when city-mayor Walter Wallmann, who governed the city between 1977 and 1986, pushed the tertiarisation of the urban economy forward and achieved a spatial re-organisation of the inner-city by providing necessary spaces. Learning from the past, this time, however, the strategy to transform the inner city was flanked by an immense investment of approximately $11 \%$ of the city's budget into the urban cultural and art sector (Noller, Ronneberger 1995). Accomplished this time by the support of private capital investments, the 'globalisation' of inner-city neighbourhoods turned out to be successful.

When reflecting on the political strategies of the 1960s, 1970s and 1980s, it becomes clear that the city actively pushed the economic structure towards a global (or at least international) entanglement. Unlike in the concept of global cities, it was not the economy that constrained the city administration to transform the urban space, but a rational strategy of the local government and investors. These developments led to a geographical and spatial duality of the urban structure, where one part of Frankfurt kept being stuck in Fordist structures (mainly the eastern part of the inner city), and the western part of the inner city being progressively pushed towards the global economy.

\section{Conclusions}

The formation of Frankfurt as a global city started early in the 1960s following a strong path dependency and profound redevelopment of inner-city neighbourhoods in the Westend. A major driving force of this transformation process was a neoliberal growth machine of mainly local economic actors and politicians. At the beginning, these developments encountered heavy resistance from parts of politically left-oriented, non-governmental groups. Later, during the 1980s, this development was carried on by a conservative growth machine with conservative politician and city-mayor Walter Wallmann as a key actor. Now, the state has camouflaged the negative social outputs of the transformation process by huge investments into the cultural sector.

As a concept, the global city brings together opposing approaches of urban theory: hierarchies and networks, economies and the social aspect, globalisation and localisation, urban form and design, the traditional understanding of urban functions as well as public control and the power exerted by the economy are reconciled into a coherent urban regime. These processes are re-ordered in a newly emerging "geography of centres and margins" (Sassen 2011: 58). The global city concept proposes a conceptual perspective of re-ordering $21^{\text {st }}$ century urbanisation. But taking a closer look at the formation of global cities between the 1960s and 1980s, it becomes clear that the concept insufficiently analyses urban fragmentation and the underlying processes of decision-making taking into account local movements and political action. An over-simplification of the global-local nexus that highlights the dominant global forces positions the local in the role of a victim of global process. Drawing on Frankfurt as an example, we have shown that there is a significant level of responsibility at the local level for explaining dramatic transformations that occurred in the eve of globalisation. 


\section{References}

Aguirre A., Eick V., Reese E., 2006. Introduction: Neoliberal globalisation, urban privatisation, and resistance. Social Justice 33(3): 1-5.

Brenner N., 1999. Globalisation as reterritorialisation: The re-scaling of urban governance in the European Union. Urban Studies 36(3): 431-451.

Brenner N., 2004. New State Spaces: Urban governance and the rescaling of statehood. Oxford University Press, Oxford \& New York.

Brenner N., Keil R., 2006. Editor's introduction: A global city - the global city. In: Brenner N., Keil R. (eds), The global cities reader. Routledge, London \& New York: 1-16.

Brenner N., Theodore N. ,2002. Preface: From the new localism to the spaces of neoliberalism. In: Brenner N., Theodore N. (eds), Spaces of neoliberalism. Urban restructuring in North America and Western Europe. Wiley, Oxford, Melbourne, Berlin: 341-347.

Castells M., 1996. The rise of the Network Society. Blackwell Publishers, Cambridge (Mass.)

Eijk G., 2010. Exclusionary policies are not just about the 'neoliberal city': A critique of theories of urban revanchism and the case of Rotterdam. International Journal of Urban and Regional Research 34(4): 820-834.

Freytag T., Hoyler M., Mager C., Fischer C., 2006. RhineMain: Making polycentricity work? In: Hall P., Pain K. (eds), The polycentric metropolis: Learning from mega-city regions in Europe. Earthscan, London: 163-171.

Friedmann J., 1986. The world city hypothesis. Development and Change 17(1): 69-83.

Hall P., 1966. The world cities. McGraw-Hill, New York.

Hannah M.G., 2012. Foucault's “German moment": Genealogy of a disjuncture. Foucault Studies 13: 116-137.

Harding A., 1995. Elite theory and growth machine. In: Judge D., Stoker G., Wolman H. (eds), Theories of urban politics. Sage Publications, London, Thousand Oaks, New Delhi: 35-53.

Harrison J., Growe A., 2012. From places to flows? Planning for the new 'regional world' in Germany. European Urban and Regional Studies. Online First.

Jonas A., Wilson D., 1999. The city as a growth machine. Critical reflections two decades later. In: Jonas A., Wilson D. (eds), The urban growth machine: Critical perspectives two decades later. SUNY Press, Albany: 3-18.

Kerber W., Hartig S., 1999. The rise and fall of the German miracle. Critical Review 13(3-4): 337-358.

Keil R., Ronneberger K., 2000. The globalisation of Frankfurt am Main: Core, periphery and social conflict. In: Marcuse P., v. Kempen R. (eds), Globalizing cities - a new spatial order? Blackwell, Oxford: 228-248.

Latham A., McCormack D., McNamara K., McNeill D., 2009. Key concepts in urban geography. Sage Publications, London, Thousand Oaks, New Delhi.

Logan L.R., Molotch H.L., 1987. Urban fortunes: The political economy of place. University of California Press, Berkeley, Los Angeles, London.
Luke T.W., 2006. Global Cities vs. global cities: Rethinking contemporary urbanism as public ecology. In: Brenner N., Keil R. (eds), The global cities reader. Routledge, London \& New York: 277-281.

Mattissek A., 2008. Die Neoliberale Stadt. Diskursive Repräsentationen im Stadtmarketing Deutscher Großstädte (The neoliberal city. Representation by discourse in the urban marketing of large German cities). Transcript, Bielefeld.

Mayer M., 2003. The onward sweep of social capital: Causes and consequences for understanding cities, communities and urban movements. International Journal of Urban and Regional Research 27(3): 110-132.

Mayer M., 2007. Contesting neoliberalism. In: Leitner H., Peck J., Sheppard E. (eds), Contesting neoliberalism: Urban frontiers. Guilford Press, New York: 90-115.

Michel B., 2010. Global City als Projekt. Neoliberale Urbanisierung und Politiken der Exklusion in Metro Manila (The Global City as a project. Neoliberal urbanisation and policies of exclusion in Metro Manila). Transcript, Bielefeld.

Mitchell D., 2000. Cultural geography: A critical introduction. Blackwell Publications, Malden, Mass.

Mössner S., 2010. Integrierte Stadtentwicklungsprogramme eine "Vertrauens-Konstellation“. Beispiele aus Frankfurt und Mailand (Integrated city development programmes - a "constellation of trust". Examples from Frankfurt and Milan). Selbstverlag Geogr. Institut, Kiel.

Noller P., Ronneberger K., 1995. Die neue Dienstleistungsstadt: Berufsmilieus in Frankfurt am Main (The new service city: Profession milieux in Frankfurt on the Main]. Campus Verlag, Frankfurt, New York.

Peck J., Tickell A., 2002. Neoliberalizing space. Antipode 34(3): 380-404.

Sassen S., 1994. Cities in a world economy. Sage, Thousand Oaks, London, New Dehli.

Sassen S., 2001. The global city: New York, London, Tokyo. Princeton University Press, Princeton, N.J.

Sassen S., 2005. The global city: Introducing a concept. Brown Journal of World Affairs 11 (2): 27-43.

Sassen S., 2011. The global city. Strategic site/ new frontier. In: Fainstein S.S., Campbell S. (eds), Readings in Urban Theory. Wiley, Malden, Oxford: 55-72.

Swyngedouw E., 1997. Neither global nor local: 'Glocalisation' and the politics of scale. In: Cox K. (ed.), Spaces of globalisation: Reasserting the power of the local. Guilford Press, New York.

Swyngedouw E., Moulaert F., Rodriguez A., 2002. Neoliberal urbanisation in Europe: Large-scale urban development projects and the new urban policy. Antipode 34(3): 542-577.

Taylor P.J., 2004. World city network: A global analysis. Routledge, London.

Theodore N., Peck J., 2011. Framing neoliberal urbanism: Translating 'commonsense' urban policy across the OECD zone. European Urban and Regional Studies 19(1): 404-419.

Touraine A., 2001. Beyond neoliberalism. Wiley, Oxford.

Walks R.A., 2009. The urban in fragile, uncertain, neoliberal times: Towards new geographies of social justice? Canadian Geographer/Le Géographe canadien 53(3): 345-356. 